\title{
Notas Sobre a Voz, Meredith Monk
}

\section{Meredith Monk *Tradução e texto introdutório de Conrado Falbo}

\begin{abstract}
Resumo
"Notes on the voice" foi publicado originalmente na revista literária The Painted Bride Quarterly, no ano de 1976, juntamente com o manuscrito comentado da partitura da obra "Our lady of late" (Monk, 1976). Em 1997 o texto foi republicado em uma coletânea organizada pela crítica de dança norte-americana Deborah Jowitt contendo alguns escritos de Monk, além de resenhas e artigos sobre sua obra (ver Monk, 1997). O texto é formado por dez notas: as nove primeiras podem ser consideradas um sumário das ideias de Monk sobre a voz, e a última é uma compilação de como estas ideias foram sendo aplicadas às suas criações até aquele momento.
\end{abstract}

Palavras-chave: voz - estudos sobre a vozMeredith Monk

\begin{abstract}
"Notes on the voice" was originally published in the literary review "The Painted Bride Quarterly", in 1976, along with the commented manuscript of the partiture of the work "Our lady of late" (Monk, 1976). In 1997 the text was republished in a collection organized by the American dance critic Deborah Jowitt, containing some writings of Monk's (see Monk, 1997). The text consists of ten notes: the first nine ones can be considered a summary of Monk's ideas about voice, and the latter is a compilation of how these ideas had been applied to her performances until that moment.
\end{abstract}

keywords: voice - voice studies - Meredith Monk 


\title{
Sobre a autora e o texto
}

Meredith Monk (Nova Iorque, 1942) é uma artista mundialmente reconhecida por seu trabalho criativo que funde elementos de diversas linguagens. É no mínimo problemático tentar classificar o conjunto de sua obra conforme os critérios tradicionais que balizam as divisões disciplinares entre modalidades de criação artística, mas isto não parece ser uma questão para a artista. Seu trabalho pode ter como resultado uma peça musical, uma coreografia, uma performance, uma ópera, um filme, ou simplesmente algo que não se enquadre em nenhuma destas categorias isoladamente, mas contenha elementos de todas elas. Em uma entrevista, Monk explica porque se considera primeiramente uma compositora (trabalhando com movimentos, sons, música, imagens):

Penso no meu trabalho como uma grande árvore com dois galhos principais. Um deles é o canto e começou com meu trabalho solo' explorando a voz humana e todas as suas possibilidades. Tenho tido uma disciplina muito forte por mais de ${ }^{30}$ anos' trabalhando com meu próprio instrumento e descobrindo todas as suas várias possibilidades. E então isso termina indo para o processo de fazer CDs e composições com o Ensemble e outros grupos que cantam minha música. Um galho é feito de todos os diferentes aspectos da música. E o outro galho é feito das formas compostas' que podem ser óperas ou obras de teatro musical' ou instalações' ou filmes. E é onde diferentes elementos são entrelaçados em uma grande composição Mas sempre sinto que estas formas são construídas de uma maneira musical Até com imagens' eu penso no ritmo como o fundamento básico que está no alicerce de tudo. E não necessariamente apenas o ritmo métrico' mas ritmo' eu diria' é o fundamento básico destes entrelaçamentos de diferentes modos perceptivos 'Monk, 200011.

A partir do final da década de 1960, a exploração das possibilidades expressivas da voz passou a ocupar um lugar central no trabalho de Monk, influenciando tudo o que vem criando desde então. O trabalho vocal desenvolvido por ela une os extremos do experimentalismo vanguardista (ao privilegiar sons tradicionalmente proscritos do repertório erudito ocidental para voz) e da ancestralidade de técnicas milenares de canto. A artista costuma repetir em entrevistas que, ainda no início de sua carreira artística, teve o que ela chama de "revelação":

\begin{abstract}
Um dia' em ${ }^{1965}$, enquanto estava ao piano vocalizando' entendi em um flash que no interior da voz estavam possibilidades ilimitadas de cor' textura' qualidade' gênero' movimento' e maneiras de produzir sons que eram universais. Daí em diante' passei a trabalhar meu próprio instrumento tentando descobrir as vozes interiores' Explorei várias ressonâncias' maneiras de usar a respiração' lábios' bochechas e diafragma. Também trabalhei com os extremos do meu registro e mudanças rápidas de uma qualidade vocal para outra' para que minha voz pudesse ser um condutor flexivel para a energia e os impulsos que começaram a emergir 'Monk' ${ }^{2003) .}$
\end{abstract}

As experiências vocais desenvolvidas por Monk consistem sobretudo em expressões não verbais: suas peças não costumam conter palavras e, quando estas estão presentes, são utilizadas muito mais como objetos sonoros que como unidades semânticas. Esta característica revela a busca da artista por investigar a voz como canal de expressão para "sentimentos para os quais não temos palavras" (Monk, 1976, p. 13), abrindo desta maneira um horizonte de significação ao mesmo tempo corpóreo, pois fundamentado na materialidade da voz, e abstrato, pois aberto a diferentes reações e interpretações por parte do público. Em vez de partir de seu papel cotidiano de mero veículo para a palavra, Monk volta-se para a voz como uma linguagem em si mesma, ampliando os limites do discurso verbal e investigando um aspecto da comunicação e da criação artística que permanece pouco explorado:

Sempre pensei na voz como uma linguagem em si mesma [...] Então' se escuto [o idioma] inglês ao mesmo tempo em que escuto o som da voz' penso nisso como duas linguagens. Se eu uso a linguagem

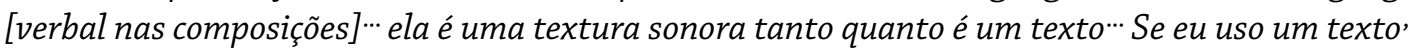
ele vai ser muito simples' e vai estar lá pelo som tanto quanto pelo significado E também acho que a música' em si mesma' é um meio muito evocativo. É muito aberto. E eu não gosto da ideia de que as pessoas precisam trabalhar através do filtro da linguagem (In Key; Rothe, 2001, $p$. 109).

\footnotetext{
$\bar{l}$ Todas as traduções são de minha responsabilidade e foram realizadas com a finalidade exclusiva de citação no presente artigo.
} 
"Notes on the voice" foi publicado originalmente na revista literária The Painted Bride Quarterly, no ano de 1976, juntamente com o manuscrito comentado da partitura da obra "Our lady of late" (Monk, 1976). Em 1997 o texto foi republicado em uma coletânea organizada pela crítica de dança norte-americana Deborah Jowitt contendo alguns escritos de Monk, além de resenhas e artigos sobre sua obra (ver Monk, 1997). O texto é formado por dez notas: as nove primeiras podem ser consideradas um sumário das ideias de Monk sobre a voz, e a última é uma compilação de como estas ideias foram sendo aplicadas às suas criações até aquele momento.

Trata-se de um raro exemplo de texto produzido pela própria artista sobre sua obra e sua visão artística, já que ela não costuma trabalhar com produções escritas, seja em forma de partituras ou artigos. A esmagadora maioria de seus depoimentos e dos comentários que fez sobre suas obras está disponível nas numerosas entrevistas que vem concedendo desde o início de sua carreira.

Além da importância destas notas como registro do pensamento artístico de Monk, pode-se dizer que elas se dirigem a questões fundamentais para os estudos da voz. As notas revelam que a artista encara a voz ao mesmo tempo como princípio/base, meio/ferramenta e fim/objeto, além de oferecer uma lista de exemplos de como aplicou estas reflexões às peças que são citadas na cronologia final. A obra que Monk vem criando desde então demonstra que ela permanece desenvolvendo basicamente as mesmas questões e que estas notas continuam sendo atualizadas a cada novo trabalho.

\section{Notas sobre a voz}

1. A voz como ferramenta para descobrir, ativar, lembrar, desvelar, demonstrar uma consciência pré-lógica/primordial.

2. A voz como meio de tornar-se, retratar, corporificar, encarnar outro espírito.

3. A voz que dança. A voz tão flexível quanto a coluna.

4. A voz como linha direta para as emoções. Todo o espectro da emoção. Sentimentos para os quais não temos palavras.

5. $\quad$ A paisagem vocal ${ }^{2}$.

6. O corpo da voz / a voz do corpo.

7. A voz como manifestação do self, persona ou personas.

8. Trabalhando com um companheiro (o instrumento acompanhante: órgão, piano, taça etc.): padrões repetidos ou ruído contínuo criando um tapete, uma tapeçaria de som para que a voz possa correr sobre, voar por cima, deslizar por baixo, prender-se e entrelaçar-se.

9. A voz como linguagem.

10. Cronologia de descobertas:

Início -

1967, dueto de voz solo com Echoplex Reverberation Unit ${ }^{3}$ (Blueprint) ${ }^{4}$, a voz livre como impulso elétrico. 1968, voz (vozes) e violino, berimbau de boca (Juice) 5 , a voz crua (rústica, lamentosa, primitiva, audaciosa), cânticos repetidos; a voz como indicativo de personalidade - a mulher da montanha vermelha, como ela soa?

\section{Continuando -}

1970, voz solo com órgão elétrico (Raw Recital, Key: An Album of Invisible Theatre), a voz viajante (movendose por paisagens de sonho).

1971, ópera épica (Vessel), a voz de Deus (alta ${ }^{6}$, transparente, contundente), telégrafo cósmico; a voz como fenômeno sobrenatural - as vozes de Santa Joana, como elas soam?

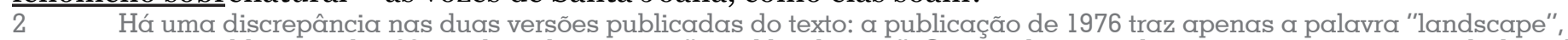

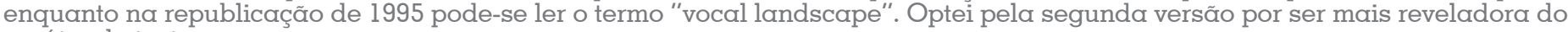
caráter do texto.

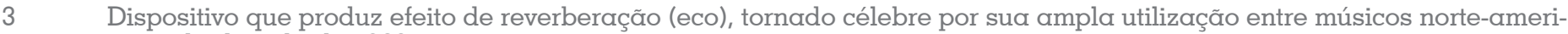
canos a partir da década de 1960.

4 As expressões entre parênteses e em itálicos são os títulos das obras criadas por Meredith Monk.

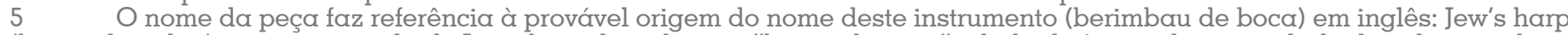

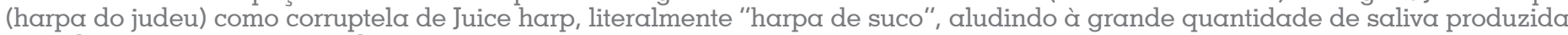
quando o instrumento é tocado por principiantes.

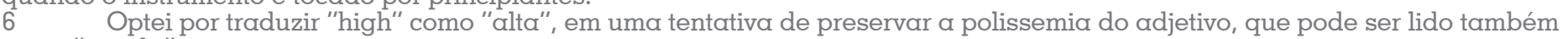
como "aguda". 
1972-3, ópera (Education of the Girlchild) a voz de um ser humano de 80 anos, a voz de um ser humano de 800 anos, a voz de um ser humano de 8 anos; raízes Celtas, Maias, Incas, Hebraicas, Atlantes, Árabes, Eslavas, Tibetanas; a voz do oráculo, a voz da memória.

1972-3, dueto de voz solo com taça (taça de vinho cheia d'água), (Our Lady of Late), a voz nua, a voz feminina em todos os seus aspectos; gradações de sentimento, nuance, ritmo, qualidade; a cada seção uma outra voz (personagem, persona), a cada seção um problema musical, uma área de investigação específica; todo o âmbito da voz (afinação, volume, velocidade, textura, timbre, respiração, colocação, força); a voz como veículo de uma jornada psíquica.

\section{Agora -}

1974, voz solo com piano (acústico) (Anthology), a voz da manhã, a voz suavizando enquanto o sol levanta, a voz derretendo e re-formando-se muitas vezes em uma canção; a voz como mensageira ou sibila; a mensageira da alma.

1975, solo para voz desacompanhada (Songs from the Hill), a voz como reflexo, espelho, receptor da natureza; vozes de animais, plantas, insetos; sinais, chamados, hieróglifos; uma oferenda à natureza; a voz, totalmente sozinha, desacompanhada, sem ornamentos.

1975-6, ópera (Quarry), 30 vozes, canções de todos os povos - acalanto, marchas, réquiem ou lamento, hinos, canções de amor, canções de trabalho; um memorial; canons ou séries de 8 e 16 partes formando um círculo invisível no ar; vozes de homens e mulheres circulando, pairando, deslizando, golpeando; vozes como uma onda de energia, uma lavagem, uma cura.

\section{Referências}

KEY, Susan; ROTHE, Larry (Org.) American mavericks: a look at 2oth century music in the United States, from the San Francisco Symphony. São Francisco: The San Francisco Symphony, 2001.

MONK, Meredith. Vocal gestures (Livro de artista). Nova Iorque: Edition Jacob Samuel, 2003.

. "Meredith Monk: composer first”, NewMusicBox, Nova Iorque, 01/04/200o. Disponível em: <http:// www.newmusicbox.org/articles/meredith-monk-composer-first/> Acesso em 15/02/2015.

. "Notes on the voice", In JOWITT, Deborah (Org.) Meredith Monk. Nova Iorque e Baltimore: Johns Hopkins University Press, 1997, pp. 57-58.

"Notes on the voice", The painted bride quarterly. vol. 3, n. 2. Filadélfia: Painted bride quarterly, 1976, pp. 13-14. Disponível em: < http://pbq.drexel.edu/wp-content/uploads/archive_pdfs/pbq_10_3_2.pdf> Acesso em 15/02/2015. 